\title{
HUBUNGAN PENGETAHUAN DAN SIKAP IBU MENYUSUI TENTANG CARA MEMERAH DAN MENYIMPAN ASI DI POSYANDU ANGGREK SANGGRAHAN JOHO SUKOHARJO TAHUN 2017
}

\section{Relationship Knowledge And Attitudes Of The Breastfeeding Mother On How To Supply And Save The Milk In Posyandu Anggrek Sanggrahan Joho Sukoharjo Year 2017}

\author{
Etik Sulistyorini1, Lilik Hanifah2 \\ STIKES Mamba’ul ‘Ulum Surakarta \\ (etik_sulistyorini@yahoo.co.id)
}

\begin{abstract}
ABSTRAK
Latar Belakang : Jumlah ibu menyusui yang melakukan penyimpanan ASI dengan benar di Indonesia masih tergolong rendah $(18,7 \%)$. Hal ini dikarenakan pengetahuan ibu menyusui tentang pentingnya pemberian ASI dengan pemahaman menyusui yang benar serta cara memerah ASI dan penyimpanan ASI masih kurang. Penelitian ini bertujuan untuk mengetahui hubungan pengetahuan dan sikap ibu menyusui tentang cara memerah dan meyimpan ASI di Posyandu Anggrek Sanggrahan Joho Sukoharjo Tahun 2017".

Metode : Penelitian ini menggunakan metode survey analitik dengan pendekatan cross sectional. Populasi penelitian ini adalah seluruh ibu menyusui di Posyandu Anggrek Sanggrahan Joho Sukoharjo yang berjumlah 38 orang. Penelitian ini tidak menggunakan sampel tetapi menggunakan subyek penelitian karena semua populasi diambil untuk diteliti. Alat pengumpul data berupa kuesioner tertutup dengan skala Guttma.

Hasil : Pengetahuan ibu menyusui tentang cara memerah dan menyimpan ASI mayoritas dalam kategori cukup dan kurang yaitu masing - masing sebanyak 12 orang $(36,4 \%)$. Sikap ibu menyusui tentang cara memerah dan menyimpan ASI mayoritas dalam kategori baik yaitu sebanyak 16 orang $(48,5 \%)$. Ada hubungan antara pengetahuan dan sikap ibu menyusui tentang cara memerah dan menyimpanan ASI dengan correlasi Kendall"s tau 0,406 pada taraf signifikansi 0,05, dan didapatkan nilai Z hitung $=3,32>Z_{\text {tabel }}=1,96$.

Simpulan: Ada hubungan antara pengetahuan dan sikap ibu menyusui tentang cara memerah dan menyimpan ASI di Posyandu Anggrek Sanggrahan Joho Sukoharjo tahun 2017.
\end{abstract}

Kata kunci: Pengetahuan, Sikap, Ibu menyusui, Cara memerah dan menyimpan ASI 


\begin{abstract}
Background: The number of breastfeeding mothers who properly storing breast milk in Indonesia is still relatively low (18.7\%). This is because the knowledge of breastfeeding mothers about the importance of breastfeeding with the correct understanding of breastfeeding and how to milk and to store breast milk still insufficient. This study aims to determine the relationship of knowledge and attitude of breastfeeding mothers about how to milk and store breastmilk in Posyandu Anggrek Sanggrahan Joho Sukoharjo in the year of 2017 ".

Method: This research use analytical survey method with cross sectional approach. The population of this study was all breastfeeding mothers in Posyandu Anggrek Sanggrahan Joho Sukoharjo which amounted to 38 people. This study did not use the sample but used the study subjects because all populations were taken for study. The data collection tool was closed questionnaire with Guttman scale.

Result: The knowledge of breastfeeding mothers about how to milk and store breastmilk majority were in enough and less category that each 12 people (36.4\%). The attitude of breastfeeding mothers about how to milk and store breastmilk majority were in good category, 16 people (48.5\%). There was a relationship between knowledge and attitude of breastfeeding mother about how to milk and store breast milk with correlation of Kendall's tau 0,406 at significance level 0,05 and got value of $Z_{\text {count }}=3,32>Z_{\text {table }}=1,96$.

Conclusion: There is a relationship between knowledge and attitude of breastfeeding mother about how to milk and store breast milk in Posyandu Anggrek Sanggrahan Joho Sukoharjo in the year of 2017.
\end{abstract}

Keywords: Knowledge, Attitude, Breastfeeding Mother, How to milk and to store breastmilk

\title{
PENDAHULUAN
}

Angka resiko kematian bayi menurut World Health Organization (WHO) adalah pada usia 9-12 bulan, maka United Nations International Children's Emergency Fund (UNICEF) dan WHO melakukan upaya untuk menangani masalah tersebut yaitu dengan cara merekomendasikan agar anak disusui Air Susu Ibu (ASI) minimal 6 bulan, dan dilanjutkan sampai anak berumur 2 tahun dengan memberi makanan pendamping ASI, karena ASI adalah makanan satu-satunya yang paling sempurna untuk menjamin tumbuh kembang bayi pada 6 bulan pertama (Infodatin, 2014).

Berdasarkan penelitian WHO di enam negara berkembang, resiko kematian bayi usia 9-12 bulan meningkat 40\% jika bayi tersebut tidak disusui. Dalam pemberian ASI, ada beberapa kendala-kendala yang ditemukan antara lain: kemampuan bayi untuk menghisap kurang, ibu yang kurang percaya diri bahwa ASI yang dimilikinya dapat mencukupi kebutuhan bayinya, dan penolong persalinan yang selalu memisahkan bayi dari ibunya segera setelah lahir, proses ini sangat mengganggu proses alamiah bayi untuk menyusu. Inti dari beberapa masalah diatas yaitu ibu belum memahami 
sepenuhnya cara menyusui yang benar termasuk teknik dan cara memperoleh ASI terutama saat mereka harus bekerja (Roesli, 2008).

Menurut hasil riset Badan Pusat Statistik (BPS) tahun 2016, Angka Kematian Bayi (AKB) adalah 25,5 per 1000 kelahiran hidup (Badan Pusat Statistik, 2016). Sedangkan menurut hasil Riset Kesehatan Dasar (Riskesdas) tahun 2016, prosentase bayi baru lahir yang mendapatkan Inisiasi Menyusu Dini (IMD) $<1$ jam adalah 50,2\% dan $\geq 1$ jam adalah 14,6 \%.4 Angka ini cenderung mengalami peningkatan dibandingkan tahun 2013 yaitu 34,5\%. Inisiasi menyusu dini dapat mengurangi $22 \%$ kematian bayi sehingga dapat mengurangi angka kematian balita 8,8\%, berarti bayi yang diberi kesempatan untuk inisiasi menyusu dini akan lebih berhasil disusui sampai usia 2 tahun bahkan lebih. Hal ini dikarenakan bayi sudah dilatih untuk minum ASI sejak awal kehidupannya, sehingga bayi tidak menginginkan susu lain (Roesli, 2008).

Cakupan pemberian ASI eksklusif sampai dengan 6 bulan adalah 42,7\% dan 0-5 bulan adlah 59,9 \% (Riskesdas, 2016). Pada tahun 2012 telah diterbitkan Peraturan Pemerintah tentang Pemberian Air Susu Ibu Eksklusif (PP Nomor 33 Tahun 2012). Dalam PP tersebut diatur tugas dan tanggungjawab pemerintah dan pemerintah daerah dalam pengembangan program ASI, diantaranya menetapkan kebijakan nasional dan daerah, melaksanakan advokasi dan sosialisasi serta melakukan pengawasan terkait program pemberian ASI Eksklusif. Menindaklanjuti hal tersebut, telah diterbitkan Permenkes Nomor 15 tahun 2013 tanggal 18 Januari 2013 tentang Tata Cara Penyediaan Fasilitas Khusus Menyusui dan/atau Memerah ASI, dan Permenkes Nomor 39 Tahun 2013 tanggal 17 Mei 2013 tentang Susu Formula Bayi dan Produk Lainnya. Selain itu, dalam rangka endukung keberhasilan menyusui sampai tahun 2013 telah dilatih sebanyak 4.314 konselor menyusui dan 415 orang fasilitator pelatihan konseling menyusui (Infodatin, 2014).

Berdasarkan Departemen Kesehatan Direktorat Bina Gizi Masyarakat tahun 2013, jumlah ibu menyusui yang melakukan penyimpanan ASI di Indonesia pada tahun 2010 sebesar 18,7\%, sedangkan di kota Surakarta masih tergolong rendah. Hal ini dikarenakan pengetahuan ibu menyusui tentang pentingnya pemberian ASI dengan pemahaman menyusui yang benar serta cara memerah ASI dan penyimpanan ASI pada ibu menyusui yang bekerja masih kurang (Depkes RI, 2013).

Masalah tersebut harus menjadi tanggung jawab dari semua praktisi kesehatan di Indonesia untuk memberikan informasi tentang pemahaman pentingnya pemberian ASI. Departemen Kesehatan melalui Keputusan Menteri Kesehatan Nomor 450/MENKES/SK/IV/2004 menetapkan bahwa semua tenaga kesehatan agar menginformasikan kepada semua ibu yang mau melahirkan untuk memberikan ASI secara eksklusif. Hal tersebut tidak akan mempunyai arti jika tidak diikuti dengan pemahaman menyusui yang benar. Adapun salah satu upaya tenaga kesehatan untuk menangani masalah tersebut antara lain: pemberian informasi tentang cara memerah ASI dan 
penyimpanan ASI bila ASI disimpan diudara terbuka/bebas bisa bertahan 6-8 jam, dilemari es $\left(4^{\circ} \mathrm{C}\right)$ bertahan 24 jam, dan di freezer $\left(-18^{\circ} \mathrm{C}\right)$ bertahan sampai 6 bulan (Hasan, 2013).

Hasil studi pendahuluan di Posyandu Anggrek didapatkan jumlah ibu yang menyusui sebanyak 38 orang, jumlah ibu yang menyusui ASI eksklusi sebanyak 16 orang, jumlah ibu menyusui yang bekerja sebanyak 8 orang, dan hanya 6 ibu yang melakukan penyimpanan ASI. Hasil wawancara pada 5 ibu menyusui, didapatkan tingkat pengetahuan ibu menyusui tentang cara memerah dan menyimpan ASI dalam kategori kurang.

Berdasarkan uraian di atas, maka peneliti tertarik untuk mengetahui "Hubungan Pengetahuan Dan Sikap lbu Menyusui tentang Cara Memerah dan menyimpan ASI di Posyandu Anggrek Desa Sanggrahan Joho Sukoharjo Tahun 2017.

\section{METODE PENELITIAN}

Penelitian ini merupakan penelitian survey analitik dengan pendekatan cross sectional. Populasi penelitian ini adalah seluruh ibu menyusui di Posyandu Anggrek Sanggrahan Joho Sukoharjo yang berjumlah 38 orang. Subyek penelitian ini semua ibu menyusui di Posyandu Anggrek Sanggrahan Joho Sukoharjo yang berjumlah 38 orang.

Pada penelitian ini menggunakan alat pengumpul data berupa kuesioner, jenis kuesioner dalam penelitian ini adalah kuesioner tertutup dengan skala Guttman. Metode pengumpulan data yang digunakan adalah pengumpulan data primer dan sekunder. Dalam penelitian ini pengumpulan data primer dilakukan dengan membagikan kuesioner secara langsung kepada ibu menyusui, sedangkan pengumpulan data sekunder dilakukan dengan cara melihat dokumen-dokumen atau catatan-catatan yang mendukung data penelitian. Analisa data dalam penelitian ini menggunakan Korelasi Kendall Tau.

\section{HASIL DAN PEMBAHASAN}

Tabel 1 Distribusi Frekwensi Karakteristik Responden Berdasarkan Umur, Pendidikan, dan Pekerjaan

\begin{tabular}{lcc}
\hline \multicolumn{1}{c}{ Karakteristik } & Frekwensi (f) & $\begin{array}{c}\text { Prosentase } \\
\text { (\%) }\end{array}$ \\
\hline Umur & 17 & \\
$16-25$ tahun & 11 & 51,5 \\
26-35 tahun & 5 & 33,3 \\
36-45 tahun & 33 & 15,2 \\
\hline Total & & 100 \\
\hline Pendidikan & 4 & \\
SD & 7 & 12,1 \\
SMP & 17 & 21,2 \\
SMA & 5 & 51,5 \\
PT & & 15,2 \\
\hline
\end{tabular}




\begin{tabular}{lcc} 
Total & 33 & 100 \\
\hline Pekerjaan & & \\
Bekerja & 15 & 45,5 \\
Tidak Bekerja & 18 & 54,5 \\
Total & 33 & 100 \\
\hline
\end{tabular}

Berdasarkan Tabel 1. dapat dilihat bahwa menurut karakteristik umur responden mayoritas adalah umur 16 - 25 tahun yaitu 17 orang (51,5\%), menurut karakteristik pendidikan mayoritas adalah berpendidikan SMA yaitu 17 orang (51,5\%), dan menurut karakteristik pekerjaan mayoritas adalah tidak bekerja yaitu ada 18 orang (54,5\%).

Tabel 2 Distribusi Frekuensi Variabel Pengetahuan Ibu Menyusui Tentang Cara Memerah Dan Menyimpan ASI Di Posyandu Anggrek Sanggrahan Joho Sukoharjo

\begin{tabular}{ccc}
\hline Pengetahuan & Frekuensi (f) & Prosentase (\%) \\
\hline Baik & 9 & 27,3 \\
Cukup & 12 & 36,4 \\
Kurang & 12 & 36,4 \\
Total (n) & 33 & 100 \\
\hline
\end{tabular}

Tabel 2 diatas menunjukkan bahwa pengetahuan ibu menyusui tentang cara memerah dan Menyimpan ASI di Posyandu Anggrek Sanggrahan Joho Sukoharjo mayoritas dalam kategori cukup dan kurang yaitu masing masing sebanyak 12 responden (36,4\%), sedangkan sebagian kecil memiliki kategori pengetahuan baik sebanyak 9 responden $(27,3 \%)$.

Tabel 3 Distribusi Frekuensi Variabel Sikap Ibu Menyusui Tentang Cara Memerah dan Menyimpan ASI di Posyandu Anggrek Sanggrahan Joho Sukoharjo

\begin{tabular}{ccc}
\hline Sikap & Frekuensi (f) & Prosentase (\%) \\
\hline Baik & 16 & 48,5 \\
Cukup & 9 & 27,3 \\
Kurang & 8 & 24,2 \\
Total (n) & 33 & 100 \\
\hline
\end{tabular}

Tabel 3 diatas menunjukkan bahwa sikap ibu menyusui tentang cara memerah dan menyimpan ASI di Posyandu Anggrek Sanggrahan Joho Sukoharjo mayoritas dalam kategori baik sebanyak 16 responden $(48,5 \%)$ dan sebagian kecil mempunyai sikap yang kurang sebanyak 8 responden $(24,2 \%)$.

Tabel 4 Hubungan Pengetahuan Dan Sikap Ibu Menyusui Tentang Cara Memerah Dan Menyimpan ASI Di Posyandu Anggrek Snggrahan Joho Sukoharjo.

\begin{tabular}{c|c|c|c|c|c|c|c|c}
\hline Pengetahuan & \multicolumn{5}{|c|}{ Sikap } & Total & $\mathbf{6}$ \\
\cline { 2 - 5 } & Baik & $(\%)$ & Cukup & $(\%)$ & Kurang & $(\%)$ & & ) \\
\cline { 2 - 4 }
\end{tabular}




\begin{tabular}{l|c|c|c|c|c|c|c|c|l}
\hline Baik & $(\%)$ & 7 & 77,8 & 2 & 22,2 & 0 & 0 & 9 & $\begin{array}{l}27, \\
3\end{array}$ \\
\hline Cukup & $(\%)$ & 7 & 58,3 & 1 & 8,3 & 4 & $\begin{array}{c}33, \\
3\end{array}$ & 12 & $\begin{array}{l}36, \\
4\end{array}$ \\
\hline Kurang & $(\%)$ & 2 & 16,7 & 6 & 50,0 & 4 & 6,4 & 12 & $\begin{array}{l}36, \\
4\end{array}$ \\
\hline Total & & 16 & 48,5 & 9 & 27,3 & 8 & $\begin{array}{c}24, \\
2\end{array}$ & 33 & 100 \\
\hline
\end{tabular}

Berdasarkan tabel 4 diketahui bahwa responden yang memiliki pengetahuan baik dengan sikap baik sebanyak 7 responden $(77,8 \%)$, dengan sikap cukup ada 2 responden $(22,2 \%)$ dan sikap kurang tidak ada. Responden yang memiliki pengetahuan cukup dengan sikap baik sebanyak 7 responden (58,3\%), dengan sikap cukup sebanyak 1 responden $(8,3 \%)$, dengan sikap kurang ada 4 responden (33,3\%). Responden yang memiliki pengetahuan kurang dengan sikap baik ada 2 responden $(16,7 \%)$, dengan sikap cukup sebanyak 6 responden (50\%) dan sikap kurang sebanyak 8 responden $(24,2 \%)$.

Tabel 5 Analisa Bivariat Kendall Tau Hubungan Pengetahuan Dan Sikap Ibu Menyusui Tentang Cara Memerah Dan Menyimpan ASI Di Posyandu Anggrek Sanggrahan Joho Sukoharjo

\begin{tabular}{clcc}
\hline \multicolumn{3}{c}{ Correlations } & \\
\hline & & Pengetahuan & Sikap \\
\hline Kendall's tau_b Pengetahuan & Correlation & 1.000 & $.406^{*}$ \\
& Coefficient & & \\
& Sig. (2-tailed) &. & .010 \\
& $\mathrm{~N}$ & 33 & 33 \\
Sikap & Correlation & $.406^{*}$ & 1.000 \\
& Coefficient & & \\
& Sig. (2-tailed) & .010 &. \\
& $\mathrm{~N}$ & 33 & 33 \\
\hline
\end{tabular}

**. Correlation is significant at the 0.05 level (2-tailed).

Berdasarkan tabel 5 diketahui hasil koefisien korelasi Kendall Tau sebesar 0,406 dengan angka signifikan 0,010. Karena N $>30$ maka signifikansi menggunakan Z tabel. Penelitian ini menggunakan Uji 2 sisi dengan $\alpha=5 \%$ maka $\alpha=5 \%=0,05: 2=0,025$. Sehingga pada tabel ditemukan nilai $\mathrm{Z}=1,96$. Karena $\mathrm{Z}$ hitung $(3,32)>\mathrm{Ztabel}(1,96)$ maka $\mathrm{H}_{0}$ ditolak dan $\mathrm{Ha}_{a}$ diterima jadi ada hubungan yang signifikan antara pengetahuan dan sikap ibu menyusui tentang cara memerah dan menyimpan ASI di Posyandu Anggrek Sanggrahan Joho Sukoharjo Tahun 2017.

Hasil penelitian pada tabel 1 dapat dilihat bahwa ibu menyusui dengan kategori pengetahuan baik sebanyak 9 responden $(27,3 \%)$ dengan 
kategori pengetahuan cukup dan kurang masing - masing sebanyak 12 responden $(36,4 \%)$.

Pengetahuan ibu menyusui dalam kategori baik, cukup, maupun kurang dikarenakan ada beberapa faktor yang mempengaruhi pengetahuan seperti faktor internal yaitu kesehatan jasmani dan rohani seseorang, termasuk didalamnya adalah kesehatan indera, kesehatan psikis, intelektual, psikomotor, serta kondisi afektif dan kognitif seseorang. Selain itu juga dipengaruhi dari faktor eksternal yang meliputi pendidikan, paparan media masa, ekonomi, hubungan sosial, pengalaman, pekerjaan, umur, lingkungan, dan intelegensi (Wawan, 2011). Berdasarkan pada Tabel 1 menunjukkan bahwa umur ibu menyusui mayoritas 16-25 tahun (51,5\%), dimana usia tersebut merupakan usia yang cukup matang dalam berfikir, bersikap dan mengambil keputusan, sehingga usia seseorang dapat berpengaruh terhadap tingkat pengetahuannya. Umur mempengaruhi terhadap daya tangkap dan pola pikir seseorang. Semakin bertambah umur akan semakin berkembang pula daya tangkap dan pola pikirnya, sehingga pengetahuan yang diperolehnya semakin membaik (Wawan, 2011).

Dari 9 responden yang memiliki pengetahuan baik tersebut jika dilihat dari latar belakang pendidikannya cukup bervariatif yaitu ada 1 responden yang berpendidikan tinggi, 3 responden berpendidikan SMA, 4 responden berpendidikan SMP, serta ada 1 responden yang hanya berpendidikan SD. Tingkat pendidikan seseorang akan berpengaruh dalam memberi respon terhadap sesuatu yang datang dari luar. Orang yang berpendidikan tinggi akan memberi respon yang lebih rasional terhadap informasi yang datang dan akan berfikir sejauh mana keuntungan yang mungkin akan mereka peroleh dari gagasan tersebut.16 Pendidikan mempunyai pengaruh dalam hal peningkatan pengetahuan seseorang, namun banyak faktor lain juga yang menyebabkan seseorang kurang dapat menyerap informasi yang diberikan melalui jalur formal pendidikan, sehingga seseorang yang berpendidikan tinggi belum tentu sepenuhnya diikuti dengan memiliki pengetahuan yang baik pula, apalagi pengetahuan yang diluar bidang pendidikan yang ditempuhnya. Sebaliknya, seseorang yang berpendidikan rendah juga belum tentu memiliki tingkat pengetahuan yang kurang. Kondisi ini dapat terjadi karena untuk saat ini banyak akses informasi untuk meningkatkan pengetahuan yang dapat ditempuh melalui jalur non formal, seperti : melalui akses internet, mengikuti kegiatan - kegiatan di lingkungan sekitar misalnya kegiatan posyandu, pendampingan ibu, dan lain-lain, juga melalui seminar, pelatihan sehingga dapat meningkatkan pengetahuan. Paparan media masa baik cetak maupun elektronik menyebabkan berbagai informasi dapat diterima dengan mudah oleh masyarakat, sehingga seseorang yang lebih sering terpapar media massa (televisi, radio, majalah, pamflet, dan lain-lain) akan memperoleh informasi lebih banyak jika dibandingkan dengan orang yang tidak pernah terpapar informasi media (Wawan, 2011).

Ibu menyusui yang memiliki pengetahuan dalam kategori cukup ada 12 responden $(36,4 \%)$, mayoritas berada dalam kategori umur 16-25 tahun 
dan 36 - 45 tahun (yaitu masing-masing ada 6 responden). Seperti telah dijelaskan diatas bahwa usia dapat mempengaruhi pola pikir dan daya tangkap seseorang. Usia 16-25 tahun merupakan masa-masa usia aktif dan produktif, sehingga seseorang cenderung aktif dalam mencari berbagai informasi yang ditunjang dengan adanya rasa keingintahuan yang besar serta dukungan akses informasi melalui media sosial yang hampir semua orang dalam kategori usia tersebut aktif mengakses dan memanfaatkan media sosial sebagai sarana informasi. Sedangkan kategori usia 36-45 tahun merupakan kategori usia yang sudah sangat matang dalam hal berfikir dan bersikap. Pada umur madya (40-60 tahun), individu akan lebih berperan aktif dalam masyarakat dan kehidupan sosial serta lebih banyak melakukan persiapan demi suksesnya upaya menyesuaikan diri menuju usia tua. Selain itu, orang umur madya juga akan lebih banyak menggunakan banyak waktunya untuk membaca, dan dari kemampuan intelektual, pemecahan masalah, maupun kemampuan verbal dilaporkan hampir tidak ada penurunan pada kategori umur ini (Wawan, 2011).

Pengetahuan ibu menyusui dalam kategori kurang ada 12 responden $(36,4 \%)$. Dilihat dari latar belakangnya mayoritas adalah ibu pekerja yaitu sebanyak 7 responden, dengan pendidikan mayoritas adalah SMA sebanyak 5 responden, dan dari segi umur mayoritas adalah umur 26-35 tahun. Pekerjaan bukan merupakan sumber kesenangan, tetapi lebih banyak merupakan cara mencari nafkah yang cenderung membosankan, berulang dan banyak tantangan. Namun persepsi setiap individu dalam menilai pekerjaannya tidaklah sama dan bergantung dari jenis pekerjaanya pula. Bekerja bagi ibu-ibu akan berpengaruh bagi kehidupan keluarganya. Orang yang bekerja seharusnya akan mempunyai pengetahuan yang lebih baik daripada orang yang tidak bekerja, karena orang yang bekerja akan banyak menerima informasi dari lingkungan maupun rekan kerjanya (Wawan, 2011). Namun, hasil penelitian menunjukkan keadaan yang sebaliknya dimana ibu menyusui yang berpengetahuan kurang sebagian besar adalah pada ibu yang bekerja, keadaan ini bisa juga dipengaruhi oleh faktor lingkungan kerja dan jenis pekerjaanya pula (dimana pada penelitian ini responden sebagian besar bekerja sebagai buruh/karyawan pabrik dengan jam kerja shift sekitar 9 jam perharinya) dan mereka dituntut untuk fokus dalam pekerjaannya. Kondisi lingkungan kerja seperti ini menyebabkan keterbatasan akses komunikasi dan informasi antar pekerja, sehingga hal ini menyebabkan tingkat pengetahuan mereka kurang walaupun berstatus sebagai pekerja. Lingkungan merupakan seluruh kondisi yang ada disekitar manusia dan pengaruhnya dapat mempengaruhi perkembangan dan perilaku orang atau kelompok (Wawan, 2011). Hasil penelitian juga menunjukkan bahwa mayoritas ibu menyusui yang pengetahuan kurang adalah berpendidikan SMA dan berusia 26-35 tahun. Walaupun ditunjang dengan latar belakang pendidikan yang cukup serta usia yang matang dan dewasa, namun masih ada faktor lain yang menyebabkan seseorang memiliki pengetahuan yang terbatas. Faktor tersebut adalah intelegensia, intelegensia 
merupakan salah satu faktor yang mempengaruhi hasil dari proses belajar. Intelegensi bagi seseorang merupakan salah satu modal untuk berfikir dan mengolah berbagai informasi secara terarah sehingga mampu menguasai lingkungan, sehingga perbedaan intelegensi dari seseorang akan berpengaruh pula terhadap tingkat pengetahuannya (Wawan, 2011).

Pengetahuan merupakan hasil tahu dan hal ini terjadi setelah orang melakukan penginderaan terhadap sesuatu objek tertentu. Penginderaan terjadi melalui panca indra manusia, yakni indra penglihatan, pendengaran, penciuman, rasa dan raba (Wawan, 2011). Selain dipengaruhi oleh faktor internal dan eksternal sebagaimana dijelaskan diatas, pengetahuan dalam domain kognitif juga memiliki tingkatan ataupun tahapan yang meliputi tahap: Tahu (know); Memahami (comprehension); Aplikasi (aplication); Analisa (analysis); Sintesis (syntesis); dan Evaluasi (evaluation) (Fitriani, 2011).

Hasil Penelitian ini memiliki kesesuaian dengan penelitian dari Ourna Damayanti mengenai Gambaran Tingkat Pengetahuan Ibu Menyusui Tentang Penyimpanan ASI di Puskesmas Gamping II Kabupaten Sleman Yogyakarta Tahun 2017, dimana hasil penelitiannya menunjukkan bahwa pengetahuan ibu menyusui tentang penyimpanan ASI mayoritas dalam kategori cukup (58,3\%) dengan karakteristik umur mayoritas umur 20-35 tahun (77,8\%), pendidikan mayoritas SMA (50\%), dan pekerjaan mayoritas wiraswasta (55,6\%) (Qurna, 2017).

Sikap ibu menyusui tentang cara memerah dan menyimpan ASI berdasarkan tabel 3 adalah mayoritas dalam kategori baik yaitu sebanyak 16 responden $(48,5 \%)$, sikap dalam kategori cukup sebanyak 9 responden $(27,3 \%)$ dan sikap dalam kategori kurang sebanyak 8 responden $(24,2 \%)$. Sikap merupakan reaksi atau respon yang masih tertutup terhadap suatu stimulus atau objek. Manifestasi sikap tidak dapat dilihat tetapi dapat ditafsirkan. Sikap merupakan kecenderungan yang berasal dari dalam diri individu untuk berkelakuan dengan pola-pola tertentu terhadap suatu objek akibat pendirian dan perasaan terhadap objek tersebut. Sikap ibu menyusui tentang cara memerah dan menyimpan ASI berada dalam kategori baik, cukup, dan kurang dapat dipengaruhi oleh beberapa faktor diantaranya adalah faktor pengetahuan, ketrampilan (skills), nilai-nilai (values), penguasaan dan kuat lemahnya perasaan, peranan, status pekerjaan, umur, pengalaman pribadi, pengaruh orang lain yang dianggap penting, pengaruh kebudayaan, media massa, lembaga pendidikan dan lembaga agama,serta faktor emosional (Azwar, 2008). Dilihat dari faktor pengetahuan, pada penelitian ini menunjukkan bahwa dari 16 ibu menyusui yang memiliki kategori sikap baik, 7 diantaranya memiliki pengetahuan yang baik pula. Kualitas dan kuantitas pengetahuan yang dimiliki seseorang, dan jenis pengetahuan apa yang lebih dikuasai seseorang tersebut dapat menentukan sikapnya. Dilihat dari status pekerjaan, dari 16 ibu menyusui yang pengetahuannya baik, ada 7 orang yang bekerja dan ada 9 responden yang tidak bekerja. Hal ini menunjukkan bahwa mayoritas ibu menyusui yang 
memiliki sikap baik adalah pada ibu yang tidak bekerja. Pekerjaan adalah kegiatan yang harus dilakukan terutama untuk menunjang kehidupannya dan kehidupan keluarga. Pekerjaan bukanlah sumber kesenangan akan tetapi lebih cenderung merupakan kegiatan yang membosankan, berulang dan banyak tantangannya bagi sebagian orang. Pekerjaan banyak menyita waktu sehingga akan mempunyai pengaruh terhadap pengalaman dan pengetahuan seseorang. Ibu-ibu menyusui yang tidak bekerja akan lebih memiliki waktu banyak untuk mendapatkan informasi ataupun berkumpul dengan lingkungan sekitar seperti melalui kegiatan pendampingan ibu, posyandu, kelas ibu, dan lain-lain yang memberikan kesempatan lebih banyak untuk meningkatkan pengetahuannya sehingga akan berpengaruh pada sikapnya pula. Sedangkan dilhat dari faktor umur, pada ibu menyusui yang memiliki sikap baik mayoritas adalah pada kategori umur 16-25 tahun yaitu ada 8 responden, 6 responden dari kategori umur 26-35 tahun, dan hanya 2 responden yang berasal dari kategori umur 36-45 tahun. Umur mempengaruhi daya tangkap dan pola pikir, semakin bertambahnya usia seseorang maka pola pikirnya akan semakin membaik, namun untuk daya tangkapnya akan semakin menurun. Semakin bertambahnya usia seseorang akan lebih memiliki sikap yang bijaksana, semakin banyak informasi yang dijumpai pula dan semakin banyak hal yang dikerjakan sehingga dapat menambah pengalaman seseorang dan akan mempengaruhi sikap seseorang. Tetapi pada umur-umur tertentu yaitu menjelang usia lanjut akan terjadi penurunan daya tangkap dan kemampuan berpikir sehingga kemampuan penerimaan atau mengingat sesuatu akan semakin berkurang (Wawan, 2011)

Hal ini sesuai dengan teori, bahwa sikap adalah suatu pola perilaku tendensi atau kesiapan antisipatif predisposisi untuk menyesuaikan diri dalam situasi sosial, atau secara sederhana dan merupakan respon terhadap stimulus sosial yang telah terkondisikan. Sikap dapat terbentuk karena adanya pengetahuan, pandangan, keyakinan, dan emosional, setelah seseorang mendapatkan stimulus atau subyek kesehatan tersebut (Wawan, 2011).

Hasil penelitian ini sejalan dengan hasil penelitian dari Anestesia Wulandari yang mengenai "Hubungan Tingkat Pengetahuan Dan Sikap Terhadap Air Susu Ibu Perah (ASIP) Dengan Praktik Pemberian ASIP Pada Ibu Bekerja Di Kalurahan Tandang Kecamatan Tembalang Kota Semarang". Hasil penelitian menunjukkan bahwa sebagian besar ibu menyusui yang bekerja memiliki sikap yang positif dalam pemberian ASIP yaitu sebanyak 21 responden $(60 \%)$, namun pada variabel praktik pemberian ASIP hanya didapatkan pada 10 responden $(28,6 \%)$, dan 6 diantaranya tidak melakukan praktik ASIP dengan baik termasuk dalam hal pemerahan ASI dan penyimpanan ASIP (Anestesia, 2012).

Berdasarkan tabel 4 menunjukkan bahwa mayoritas ibu menyusui yang mempunyai pengetahuan baik tentang cara memerah dan menyimpan ASI mayoritas juga memiliki sikap yang baik pula mengenai hal tersebut. Dari 
9 responden yang memiliki pengetahuan baik, 7 diantaranya memiliki sikap yang baik pula (77,8 \%). Dari 12 responden yang memiliki pengetahuan cukup, 7 diantaranya memiliki pengetahuan baik (58,3\%), dan dari 12 responden yang memiliki pengetahuan kurang, hanya ada 2 responden yang memiliki sikap baik (16,7 \%). Hasil ini menunjukkan bahwa semakin baik pengetahuan seseorang, maka semakin baik pula sikapnya. Penelitian ini menggunakan koefisien korelasi Kendall Tau sebesar 0,406 dengan angka signifikan 0,10 . Karena $\mathrm{N}>30$ maka signifikansi menggunakan $\mathrm{Z}$ table dengan Uji 2 sisi dengan $\alpha=5 \%$, maka $\alpha 5 \%=0,05: 2=0,025$. Pada T tabel ditemukan nilai $\mathrm{Z}=1,96$ dengan hasil $\mathrm{Z}$ hitung $(3,32)>\mathrm{Z}$ tabel $(1,96)$ maka $\mathrm{H}_{0}$ ditolak dan $\mathrm{H}_{\mathrm{a}}$ diterima, dengan kesimpulan bahwa ada hubungan pengetahuan dan sikap ibu menyusui tentang cara memerah dan menyimpan ASI di Posyandu Anggrek Sanggrahan Joho Sukoharjo.

Seseorang yang telah mendapatkan pengetahuan melalui pengamatan akan mendapatkan suatu respon terhadap suatu objek, dari respon tersebut akan membantu membentuk seseorang dalam bersikap (Azwar, 2008). Hubungan yang positif ini mempunyai arti bahwa semakin baik pengetahuan tentang cara memerah ASI dan menyimpan ASI pada ibu menyusui akan semakin meningkatkan sikap positif nya yaitu dalam melakukan cara pemerahan dan penyimpanan ASI dengan benar. Pengetahuan yang baik merupakan hal penting bagi ibu menyusui, sehingga dapat membantu ibu menyusui untuk menghadapi masalah yang bersumber dari ketidaktahuan dalam hal bagaimana cara memerah ASI dan menyimpan ASI yang baik. Jika ibu menyusui mempunyai pengetahuan yang baik tentang bagaimana cara memerah dan menyimpan ASI perah yang baik, maka kemungkinan besar akan berfikir untuk menentukan sikap dan berperilaku mencukupi kebutuhan ASI bagi bayinya walaupun ibu tersebut tetap beraktivitas sebagai pekerja. Ibu tidak akan khawatir lagi bayinya mengalami kekurangan ASI, karena ASI sangat penting bagi bayi. ASI merupakan sumber gizi yang sangat ideal dengan komposisi yang seimbang dan disesuaikan dengan kebutuhan pertumbuhan bayi. ASI adalah makanan bayi yang paling sempurna, baik kualitas maupun kuantitasnya dengan tatalaksana menyusui yang benar. ASI merupakan faktor utama yang mempengaruhi perkembangan kecerdasan pertumbuhan otak. Dengan memberikan ASI secara eksklusif sampai bayi berusia 6 bulan akan menjamin tercapainya pengembangan potensi kecerdasan anak secara optimal. Hal ini karena selain sebagai nutrien yang ideal, dengan komposisi yang tepat, serta disesuaikan dengan kebutuhan bayi (Anestesia, 2012).

Hal ini sesuai dengan teori pengetahuan yang merupakan hasil tahu dan hal ini terjadi setelah seseorang melakukan penginderaan terhadap suatu objek tertentu (Wawan, 2011). Penginderaan terjadi melalui panca indra manusia yaitu indra penglihatan, pendengaran, penciuman, peraba, dan perasa. Pengamatan adalah salah satu dari penginderaan suatu objek yang melalui panca indera, dari penginderaan suatu objek akan menghasilkan 
sebuah pengetahuan. Seseorang yang memiliki pengetahuan maka akan terbentuk pula suatu sikap (Azwar, 2008)

Sikap mempunyai segi- segi motivasi dan segi-segi perasaan, sifat alamiah yang membedakan sikap dan kecakapan-kecakapan atau pengetahuan-pengetahuan yang dimiliki orang. Orang bersikap positif atau negatif terhadap suatu objek sikap dibentuk melalui pengamatan pada perilaku sendiri. Sikap adalah suatu pola perilaku, tendensi atau kesiapan antisipatif, predisposisi untuk menyesuaikan diri dalam situasi sosial, atau secara sederhana, dan merupakan respon terhadap stimulus sosial yang telah terkondisikan (Wawan, 2011). Sikap dibagi menjadi dua yaitu sikap positif dan negatif. Sikap positif tentang cara memerah dan penyimpanan ASI adalah sikap terhadap kebiasaan yang baik untuk senantiasa agar dapat memenuhi kebutuhan ASI pada bayinya melalui ASI perah yang dilakukan penyimpanan dengan benar sehingga kualitas ASI tetap terjaga. Sedangkan sikap negatif tentang cara memerah ASI dan penyimpanan ASI adalah sikap dari ibu menyusui yang tidak memiliki keinginan untuk memberikan ASI nya kepada bayinya dengan alasan karena berstatus sebagai pekerja sehingga tidak memiliki waktu untuk memberikan ASI walaupun sebenarnya ASI nya dapat diberikan melalui cara diperah dan disimpan sebagaimana mestinya.

Hasil penelitian ini sejalan dengan penelitian yang dilakukan oleh Anestesia Wulandari tahun 2012, yang menunjukkan bahwa ada hubungan antara tingkat pengetahuan tentang ASIP dengan praktik pemberian ASIP di kelurahan Tandang Kecamatan Tembalang Kota Semarang, dimana responden dengan tingkat pengetahuan baik menunjukkan prosentase dalam pemberian ASIP yang lebih besar pula dibandingkan dengan responden yang tingkat pengetahuannya kurang dengan hasil uji Fisher Exact menunjukkan $\mathrm{p}$ value $=0,028(<0,05)$. Terbentuknya perilaku seseorang salah satunya ditentukan oleh pengetahuan seseorang. Perilaku akan dipermudah apabila seseorang mempunyai sikap yang positif terhadap sesuatu yang akan dikerjakan. Terbentuknya suatu perilaku baru terutama pada orang dewasa biasanya dimulai dari ranah kognitif, dimana subjek terlebih dahulu akan dimulai dari adanya stimulus yang menimbulkan pengetahuan baru. Pengetahuan tersebut akan menimbulkan respon batin dalam bentuk sikap tertentu. Stimuus yang telah diketahui dan disadari tersebut akan menimbulkan respon yang lebih jauh lagi yaitu berupa tindakan (Anestesia, 2012).

Hasil penelitian ini juga mendukung penelitian sebelumnya yang dilakukan oleh Yuni Puji Widiastuti mengenai "Hubungan Pengetahuan Dan Sikap Dengan Pemberian ASI Eksklusif Oleh Ibu Yang Bekerja Sebagai Perawat Di RSUD Dr. H. Soewondo Kendal" yang menunjukkan bahwa ada hubungan yang sigifikan antara pengetahuan ibu yang bekerja sebagai perawat dengan pemberian ASI Eksklusif, dengan nilai $p$ value sebesar 0,004 nilai $\mathrm{p}<0,05$ dan nilai OR - 0,550 yang artinya pengetahuan ibu yang baik mempunya peluang 0,550 kali untuk memberikan ASI Eksklusif dibandingkan ibu tidak memberikan ASI Eksklusif. Hasil penelitian juga 
menunjukkan bahwa Ada hubungan yang signifikan antara sikap ibu yang bekerja sebagai perawat dengan pemberian ASI Eksklusf, dengan nilai $p$ value sebesar 0,000 nilai $\mathrm{p}<0,05$ dan nilai $\mathrm{OR}=61,333$ yang artinya sikap ibu yang baik mempunyai peluang 61,333 kali untuk memberikan ASI Eksklusif dibandingkan tidak memberikan ASI Eksklusif (Yuni, 2011).

Penelitian yang dilakukan oleh Lina pada tahun 2016 mengenai "Hubungan Pengetahuan Dengan Cara Memerah ASI Pada Ibu Menyusui Yang Bekerja Di Desa Matang Seulimeng Kecamatan Langsa Barat Kota Langsa"juga menunjukkan adanya hubungan yang signifikan antara pengetahuan ibu dengan cara memerah ASI. Hasil uji Chi-Square (Pearson Chi-Square) pada derajat kepercayaan $90 \%$ menghasilkan $p$ value $0,000(p<$ $0,05)$. Secara proporsional terlihat bahwa pada responden yang memerah ASI dengan tehnik yang benar sebagian besar mempunyai pengetahuan baik (66,7 \%), dan responden yang memerah ASI dengan cara yang salah sebagian besar memiliki pengetahuan yang kurang $(77,8 \%)$. Pelaksanaan memerah ASI dengan baik dan benar sangat dipengaruhi oleh pengetahuan dan sikap, dikarenakan pengetahuan akan menimbulkan respon batin dalam bentuk sikap tertentu. Semakin baik respon batin dalam bentuk sikap tertentu maka semakin baik pula perilakunya. Sebaliknya semakin buruk respon batin dalam bentuk sikap maka semakin buruk pula perilakunya (Lina, 2016).

\section{Simpulan}

\section{SIMPULAN DAN SARAN}

Pengetahuan ibu menyusui tentang cara memerah dan menyimpan ASI di Posyandu Anggrek Sanggrahan Joho Sukoharjo Tahun 2017 mayoritas dalam kategori cukup dan kurang yaitu masing - masing sebanyak 12 orang (36,4\%). Sikap ibu menyusui tentang cara memerah dan menyimpan ASI di Posyandu Anggrek Sanggrahan Joho Sukoharjo Tahun 2017 mayoritas dalam kategori baik yaitu sebanyak 16 orang (48,5\%), Ada hubungan antara pengetahuan dan sikap ibu menyusui tentang cara memerah dan menyimpan ASI di Posyandu Anggrek Sanggrahan Joho Sukoharjo Tahun 2017 yaitu dengan nilai koefisien korelasi sebesar 0,406 dengan taraf signifikan 0,10 dan Zhitung $=3,32>Z_{\text {tabel }}=1,96$.

\section{Saran}

Bagi Posyandu Anggrek Sanggrahan Joho Sukoharjo Dari hasil penelitian ini diharapkan dapat memberikan masukan bagi warga masyarakat khususnya ibu menyusui tentang pentingnya untuk mengetahui cara memerah dan menyimpan ASI yang benar, sehingga kebutuhan ASI untuk bayi terpenuhi. Bagi Tenaga Kesehatan diharapkan dapat berkerja sama dengan intitusi pendidikan guna penyuluhan kesehatan secara rutin kepada masyarakat khususnya tentang cara memerah dan menyimpan ASI. Bagi Responden Diharapkan ibu menyusui dapat meningkatkan pengetahuan dan informasi tentang cara memerah dan menyimpan ASI melalui media yang benar agar dapat meningkatkan pemahamannya dan 
dapat menyediakan ASI dengan kualitas dan kuantitas yang baik bagi bayinya.

\section{DAFTAR PUSTAKA}

Anestesia Wulandari. 2012. Hubungan Tingkat Pengetahuan Dan Sikap Terhadap Air Susu Ibu Perah (ASIP) Dengan Praktik Pemberian ASIP Pada Ibu Bekerja Di Kalurahan Tandang Kecamatan Tembalang Kota Semarang.. http://download.portalgaruda.org/article.php._Diakses 6 Nopember 2017 Jam 15.32 WIB.

Azwar, S. 2008. Sikap Manusia Teori dan Pengukurannya Edisi kedua. Yogyakarta : Pustaka Pelajar.

Badan Pusat Statistik. 2016. Statistik Demografi. https://databoks.katadata.co.id/. Diakses 6 Oktober 2016 jam 10.54 WIB.

Infodatin. 2014. Situasi dan Analisis ASI Eksklusif. http://www.depkes.go.id/download/pusdatin/infodatin/infodatinasi.pdf Diakses: 4 Oktober 2016 jam 12.02 WIB.

Departemen Kesehatan RI. 2013. Menyusui dan Kesehatan. http://www.Depkes.go.id Di akses 11 Oktober 2014 jam 11.16 WIB.

Fitriani, Sinta. 2011. Promosi Kesehatan. Yogyakarta: Graha Ilmu

Hasan R, Hasdianah. 2013. Buku Ajar Kesehatan Reproduksi. Yogyakarta: Nuha Medika

Lina. Tahun 2016. Hubungan Pengetahuan Dengan Cara Memerah ASI Pada Ibu Menyusui Yang Bekerja Di Desa Matang Seulimeng Kecamatan Langsa Barat Kota Langsa Tahun 2016. http://nasuwakesaceh.ac.id/gudang/file/pdf/jurnal-pdfgSKt0Js284a8L43d.pdf. Diakses 10 Nopember 2017 Jam 09.14 WIB

Qurna Damayanti. 2017. Gambaran Tingkat Pengetahuan Ibu Menyusui Tentang Penyimpanan ASI Di Puskesmas Gamping II Kabupaten Sleman Yogyakarta.

http://repository.stikesayaniyk.ac.id/1344/2/OURNA\%20DAMAYANTI \%20\%281114082\%29nonfull.pdf. Diakses 3 Nopember 2017 Jam 14.02 WIB

Roesli, Utami. 2008. Inisiasi Menyusu Dini Plus ASI Eksklusif. Jakarta: Pustaka Bunda

Riskesdas. 2016. Profil Kesehatan Indonesia Tahun 2016. http://www.depkes.go.id/resources/download/pusdatin/profilkesehatan-indonesia/Profil-Kesehatan-Indonesia-2016.pdf. Diakses 6 Oktober 2016 Jam 11.09 WIB.

Wawan, A dan Dewi, M. 2011. Pengetahuan Sikap dan Perilaku Manusia. Yogyakarta: Nuha Medika

Yuni Puji Widiastuti. Tahun 2011. Hubungan Pengetahuan Dan Sikap Dengan Pemberian ASI Eksklusif Oleh Ibu Yang Bekerja Sebagai Perawat Di RSUD Dr. 
Avicenna Journal of Health Research. Vol 1 No 1. Maret 2018 (40 - 54)

H.SoewondoKendal.http://www.stikeskendal.ac.id/media/file/798376

55182artikel ASI APTIKES CMC.pdf. Diakses 10 Nopember 2017 Jam 8.40 WIB 